\title{
TECHNOLOGICAL INNOVATION AND CAPITAL ACCUMULATION IN SUB-SAHARAN AFRICA: IMPLICATIONS FOR RURAL DEVELOPMENT
}

\author{
Harland Prechel \\ State University of New York at New Paltz
}

Mid-American Review of Sociology, 1986, XI, No. 1

Development policy and the role of technology in the capital accumulation process has been a subject of controversy since the 1960s. This paper reviews the divergent opinions on this issue, critiques development policy in sub-Saharan Africa, and analyzes how its connection to the global economy affects Africa's ability to accumulate capital and realize longterm growth. The paper demonstrates that the urban-oriented modernizationist policies of the 1960s and 1970s have hampered sub-Saharan Africa's ability to feed its expanding population. The analysis suggests that internally directed agricultural development must proceed externally-oriented urban-industrial development.

\section{INTRODUCTION}

Technology is a key variable in the development process because it can increase production while lowering the cost of goods and services. However, because the effects of technological change are complex and widespread little consensus exists on the type of technology that should be implemented, ${ }^{1}$ its role in the production process, or the rate at which technological change should occur. Moreover, the implementation of technology has become the subject of ideological and theoretical debates. For example, modernization theorists insist that decisions to.implement technology are "value-free" and benefit all members of society. In contrast, dependency theorists argue that decisions to implement technology encourage city-centered capital intensive development, and provide direct benefits to the domestic and foreign capitalist classes (for detail see pp. 5-7).

Within this paper I will critically review the major perspectives on the development process and the importance these arguments place on technology. Morevover, I will discuss the effects of capital investment policies on the development process, ${ }^{2}$ demonstrate that the low agricultural output in sub-Saharan Africa is largely due to a failure to introduce rural develop- 
ment programs, and present an alternative development strategy.

\section{CONCEPTIONS OF TECHNOLOGICAL DIFFUSION}

Much of the initial research (i.e. 1950s-1960s) on less developed countries (LDCs) was conducted within the framework of modernization theory. Modernization theorists argue that cultural barriers are the key obstacles to economic and social development. According to modernization theory the development of modern attitudes, values, and behavior through formal education is the most effective method to ensure the adoption of modern production technologies (Inkeles and Smith, 1974:33, 313; also see Malik, 1982; Vajpeyi, 1982). Modernizationists hold that the rapid transfer of technology into the industrial sector of LDCs is central to the development process, and an urban-industrial economic base is necessary to ensure economic development (Inkeles and Smith, 1974; Rostow, 1971; Eisenstadt, 1966). This argument suggests that the implementation of modern technology into the export-oriented urban-industrial sector will stimulate growth and encourage technological diffusion.

Modernizationists also argue that because LDCs have different cultures, social structures, and economic systems, a global theory of underdevelopment is impossible (Thompson, 1978). Moreover, they refuse to acknowledge that the political and economic actions of Europe and the U.S. (e.g., colonialism and imperialism) have interfered with development in LDCs. Modernizationists argue that their recommendations to implement urban-industrial technology are based on scientific research and consequently are "valuefree." This attempts to depoliticize policy formation (for more detail on the idenlogical dimensions of modernization theery- sse Prechel and Sica, 1986).

Similar to the modernizationist's, advocates of appropriate technology emphasize diffusion in their conceptions of technological innovation. They maintain that the degree of economic, social, and cultural ${ }^{3}$ heterogeneity is high among developing countries, and these variables must be considered before development strategies are adopted (see Jequier, 1979; Hannay and McGinn, 1980). From the appropriate technology perspective the ultimate dilemma of capital-intensive development is the unemployment it generates and the subsequent unused human resources. To avoid these problems they argue that technology must become diffused throughout the society (see Critchfield, 1982:32). Hence, technological diffusion is a cornerstone to their conceptualization of the development processes.

However, in contrast to modernization theory, supporters of appropriate technology are critical of the capital intensive and city-centered transfer of technology. They point out that this strategy has produced the wrong types of goods to meet the needs of the poor, increased unemployment, and required an infrastructure that is not compatible with the socio-cultural conditions (McRobie, 1979). Moreover, they maintain that any development strategy must be conceptualized with an understanding that a hierarchy of technologies exists, and the appropriateness of the technology is based on the degree of scarcity or surplus that exists within these societies (Robinson, 1979:29).

Affiliates of E.F. Schumacher's Intermediate Technology Development Group view LDCs at an intermediate level of technological sophistication. They argue that "development is an organic growth and that to intermediate levels of development there must correspond intermediate levels of technologies" (Porter and Latham-Koenig, 1969:43). These technologies exist somewhere between relatively simple equipment and machines, and capital intensive technologies currently used in industrialized countries (Agarwal, 1980). The appropriate technology position places a strong emphasis on technical 'know-how,' and advocates the development of small-scale production (Schumacher, 1973:179). Although minor differences exist among the various appropriate technology positions they all emphasize historicalcultural uniqueness, employment intensification, and discourage technology transfers that threaten to generate unemployment.

Although their argument that capital-intensive technology increases unemployment may be accurate in some LDCs, it is an oversimplification and subsequently inaccurate portrayal of sub-Saharan Africa. Unemployment in sub-Saharan Africa is primarily a consequence of urban migration. Captial interisive technologies have traditionally been introduced into the urban areas. The increased productivity of this economic sector makes it possible to pay the few workers employed high wages, which encourages urban migration. Unemployment is caused by uneven development in selected urban centers where production and wages increase while they remain low in the rural areas. In other words, the decision to introduce technology in the urban-industrial sector generates unemployment. This problem is not inherent in the technology.

The appropriate technology strategy has also been challenged on the premise that it results in low productivity and suppressed wages (e.g. Baron, 1980:32-33). It has been demonstrated that the adoption of labor intensive technology may backfire as the equipment becomes obsolete and more capital intensive technology is able to produce the commodity cheaper elsewhere 
(Nwosu, 1975:89). Once this occurs the entrepreneur must increase labor exploitation and suppress wages to successfully compete in the global economy. Moreover, capital accumulation is retarded and economic growth does not occur. A fundamental contradiction of this strategy, for LDCs, is that their developed counterparts in North America and Europe continue to upgrade their technology which increases the already significant gap in productivity.

Although the appropriate technology and modernization positions are substantively different they share one important weakness: both fail to recognize how integration of LDCs into the global economy affects the development process. On the one hand, modernizationists deny that technological innovation into urban-oriented economic development results in export-oriented development that benefits specific segments of the population. On the other hand, the appropriate technology position fails to recognize the consequences of the capital accumulation limitations of laborintensive technology; these less productive technologies will perpetuate the existing economic divisions within LDCs, and increase the gap between LDCs and their developed counterparts. ${ }^{4}$

For example, Stewart and Streeter (1976) point out that the trickle-down (i.e. diffusionist) theory does not hold. Instead of receiving the benefits of growth in the urban-industrial sector, workers employed in the rural sector remain underemployed and their economic position declines in both relative and absolute terms. It is the uneven application of technology, uneven wages, and inflation that generates this inequality. In addition, wages in LDCs are increasingly determined through international competition which results in further exploitation. For example, in Hong Kong and Singapore where labor costs.are rising, transnational corporations are reducting production rates, and manufacturing is being shifted to Malaysia, El Salvador, Thailand, and Indonesia where labor and production costs are lower (Landsberg, 1979; Barnet and Muller, 1974; Bluestone and Harrison, 1982). The international labor market forces workers to compete against one another by selling their labor cheaper than workers in other LDCs. In short, because of the disparities in production rates in the global economy whatever surplus LDCs are able to obtain is extracted from the already underpaid workers. As a result, workers receive subsistence wages and are unable to purchase consumer goods. Most importantly, labor-intensive technologies perpetuate the existing differences in production rates.

In short, the diffusionist (e.g. modernization, appropriate technology) conceptions of technological innovation do not recognize the complexities of the effects of the global economy, and therefore are unable to provide a strategy for long-term sustained development. In addition, because they place technological innovation at the center of their analysis, both positions underplay the political-economic dimensions of the development process.

\section{DEPENDENCY THEORY: A POLITICAL AGENDA}

The lack of technological diffusion and the failure of this development strategy to stimulate economic and social prosperity has resulted in widespread criticism of modernization theory. For example, Frank (1967) demonstrated that modernizationist's policies generate growth in isolated urban-industrial sectors of the economy and underdevelopment in other sectors. Moreover, the export-orientation of the economy results in dependence and the extraction of substantial amounts of wealth (Amin, 1974; Emmanuel, 1972) and increases debt (Bodenheimer, 1971).

Other dependency theorists maintain that the critical issue is the way in which developing countries have been integrated into the global economy. Amin (1976:360) argues that class alliances between local elites and foreign capitalists play a critical role in this process (also see Bradshaw, 1985). Moreover, these class alliances are established prior to the delegation of technology to the various economic sectors. For Amin, class relations are the foundation of the global economy and technology is important only because of its contribution to productivity. These theorists suggest that the way in which technology is transferred (e.g. into economic sectors controlled by foreign capital) denies LDCs the opportunity to direct their social and economic development, become self-reliant, and receive the benefits of the capital accumulation. In short, their relationship to the global economy, not the introduction of technology, is the source of their inability to generate sustained economic growth.

Dependency theorists charge that modernizationist strategy has encouraged capital intensive export-oriented urban-industrial development (Barratt-Brown, 1974). Alliances are formed among transnational corporations, local capital, and the state to facilitate growth in the sectors most easily organized and controlled. Local elites supply commercial expertise and information on potential customers, which enables transnational corporations to expand into domestic industries (Evans, 1979:131-58; also see Evans, 1977). Such an alliance enriches foreign corporations and peripheral elites, while it centralizes political authority. This suggests that there is an inherent 
political dimension to the development process: peripheral elites influence government policies and reap the economic benefits from these international class alliances. Moreover, state policies have encouraged the production of specialty products for export in the agricultural sector. This type of agricultural policy results in the displacement of crops for domestic consumption, which increases the need to import food.

Most importantly, these class alliances generate a non-creative capitalism characterized by limited capacity to accumulate capital, which results in the failure to stimulate independent economic development (see Amin, 1974, 1976; Fanon, 1967). Furthermore, the export-orientation of these policies increases domestic income inequality (Prechel, 1985). In short, this type of integration into the global economy limits economic growth to specific areas, retards investment into the non-urban segment of the production process, ${ }^{5}$ and perpetuates inequality.

The presence of these alliances has led dependency theorists to argue that technology receives too much attention in the development process (e.g. Amin, 1976; Emmanuel, 1974; Magdoff, 1978). Dependency theory emphasizes the effects technology has on the social relations of production and the inequalities they generate. In other words, technology is not the central issues and by focusing on technological diffusion the decision-making process becomes depoliticized. Magdoff (1978) maintains that the emphasis on technology has obscured the real issues, and that social needs as well as economic gains must be considered. Emmanuel $(1972,1974)$ shares this view and argues that confusion exits between industrialization and mechanization, and their respective roles in the development process. $\mathrm{He}$ argues that these concepts must be demystified and we must return to the notion: $\rightarrow \ldots+\ldots$.

that the only conceivable purpose of development is to improve men's material wellbeing... Industrialization, manufacturing, mechanization and so forth, can be means to attain this end, and it would be absurd and ridiculous to regard them as ends in themselves (Emmanuel, 1974:64).

The self-reliant strategy of technological innovation-a dependency perspective-poses an alternative to diffusionist strategies. Self-reliance stresses a mix of capital and labor intensive technologies in an effort to generate sustained independent development.
[Self-reliant development] implies the autonomous definition of development of the 'life-styles' to stimulate creativity and to lead to a better use of production, and to reduce vulnerability and dependency, so that societies can rely more on their own forces of resistance, have confidence in themselves, and be dignified (Cardoso, 1982 161).

This notion holds that the selective transfer of technology is crucial to initiate sustained development, and the transfer of technology under specified guidelines can lead to the autonomous creation of technology (Cardoso, 1982: 162). To stimulate rapid economic growth self-reliance supports the transfer of capital intensive technology, while emphasizing the conscientious use of physical and human resources. One of the major goals of this strategy is to encourage local production for local consumption rather than production for export.

The self-reliant approach argues that if production is designed for domestic consumption a larger proportion of the population will become actively involved in the economy, and the transfer of technology will be closely scrutinized. This involvement ensures the development of a production system that is compatible with the local culture and social structure. The theory holds that production for local consumption will generate interest in the economic system, better meet the basic needs of the domestic population, stimulate creativity, and reduce alienation. This enhances production diversity, reduces trade dependency by expanding production into more areas, and stimulates local trade. Cardoso (1982) maintains that the self-reliant approach is the only viable strategy to reduce the economic disparities between developed countries and LDCs and diminish the gaps between 'over-developed pockets' and the larger underdeveloped areas in LDCs (also see Galtung, 1980:398-413).

\section{TRADITIONAL APPLICATIONS OF CAPITAL INTENSIVE TECHNOLOGY}

A major source of inadequate development within LDCs is the sectoral development of their economies. The economy of many LDCs can be divided into two general categories. First, there is the industrial and raw material sectors where foreign investors have introduced capital intensive techniques. Second, there are sectors which remain primarily agricultural where foreign investment is low. ${ }^{6}$ In Africa, because agricultural production is difficult to organize, the agricultural sector has not become involved in the global 
economy to the same degree as other sectors. As a consequence the agricultural sector has had the good fortune of remaining more economically independent. On the other hand, it depends on labor intensive technology, which keeps production levels low and retards capital accumulation.

To correct the retarded rate of development, Amin contends it is absolutely necessary to get out of the vicious circle of 'poverty of capital' (1974:207; also see Thirlwall, 1962:82-89). ${ }^{7}$ That is, methods that facilitate rapid capital accumulation must be implemented to foster economic growth. He also argues that capital intensive development must be pursued even where substantial unemployment exists, and maximum employment should only be pursued where the most labor intensive technique is also really capital-saving; where mechanization would enable labor to be saved without adequately increasing productivity (Amin, 1974:216). ${ }^{8}$ In essence, Amin suggests that development decisions in LDCs should not be different than those made in industrialized countries. Of the technologies available the most productive technique should be chosen. He maintains that this is the only way to generate long-term economic growth, maximize surplus, and increase wages.

\section{DEPENDENT-DEVELOPMENT IN SUB-SAHARAN AFRICA}

Although some of sub-Saharan Africa's current economic problems are related to its recent droughts, declines in per capita income are largely a consequence of its connection to the global economy (e.g. slow growth; recessions).${ }^{9}$ Moreover, the restrictive monetary policies to control inflation in developed countries, and the subsequent reduction in demand for export products has resulted in a balance of payment crisis in several subSaharan countries (see World Bank, 1984).

Because of its specialized connections to the global economy, Nigeria-the dominant economy in West Africa-is having major economic problems. Prompted by high returns on oil in the 1970s Nigeria developed its petroleum industry and became dependent almost exclusively on the oil sector for foreign exchange to finance its industrial growth. In 1980, 24 percent of Nigeria's GDP was obtained from oil export; oil revenues accounted for 95 percent of its total export earnings, and 85 percent of total government revenues (World Bank, 1982a:69). However, world exports of oil declined by 14 percent between 1981 and 1982 . As a result of the decreased demand for oil, Nigeria has experienced serious cash-flow problems, which have impeded the implementation of development projects. Consequently, the
Nigerian economy, previously the fastest growing economy in Africa, showed marginal growth in 1982 (World Bank, 1982a:69) and Nigerian foreignexchange reserves declined substantially in 1983 (World Bank, 1983a:71). Moreover, the sharp drop in the price of oil resulted in financial crisis during most of 1984 (World Bank, 1984:88). The lack of foreign exchange forced a reduction of imports and limited the supply of raw materials and spare parts which led to widespread plant closures, extensive layoffs, and a substantial drop in the utilization of production capacity. As a result it was estimated that the manufacturing sector operated at only 30 percent of capacity (World Bank, 1985:93). In 1985, GNP declined by 2.8 percent and per capita income deteriorated by 5 percent (World Bank, 1984:85-90, 1985:93-97).

Although the economy of the Ivory Coast is more oriented to agriculture, its dependence on exports has resulted in similar problems. Because of the drop in coffee and cocoa prices their terms of trade deteriorated by 40 percent between 1977 and 1982. This trend is dominant within most other West African countries (see World Bank, 1982a), and several are experiencing a balance-of-payments crisis (World Bank, 1983a:67). In addition, GDP grew so slowly in the early 1980s that per capita income declined throughout Sub-Saharan Africa (World Bank, 1981a:1; 1983a:70).

East African economies have similar problems. Their GDP has declined significantly because of a deterioration in their terms of trade (World Bank, 1982a:63; 1984:89,85,). The loss of revenue is due to price reduction of seven export commodities-tea, coffee, copper, cotton, sugar, tobacco, and sisal in the global marketplace. These commodities account for about 70 percent of the region's exports. This loss of revenue has severely hampered East Africa's export earnings, which it is dependent upon for economic growth. Price reductions of minerals in the global economy have caused economic problems in Zaire and Zambia (World Bank, 1982a:94) and per capita income fell 44 percent between 1974 and 1985. In Zambia, reduced demand for its export commodities lowered capacity utilization. As a result, capital investments fell from 41 percent of GDP in 1975 to 12 percent in 1984 (World Bank, 1985:90). The reduction of capital investments undermines capital formation, which is the variable dependency theorists argue is critical to ensure long-term economic growth (e.g. Amin, 1974, 1976). The loss of capital from exports has required a reduction of spending on social and economic investment programs by 50 percent in some countries (World Bank, 1983:36).

Changes in the global economy have also undermined sub-Saharan Africa's terms-of-trade. For example, the combined index of export prices $(1978-80=100)$ for Eastern and Southern Africa countries declined from 
116 in 1980 to 81 in 1982 (World Bank, 1985:86). In 1984, the estimated weighted export-price index for East Africa was 20 percent lower than the average for 1978-80 (World Bank, 1984:81). The price of their major export commodities (e.g. copper, coffee, cobalt, cotton, sugar) are not expected to increase in real terms throughout the 1980 s, and may drop to 15 to 20 percent lower than they were in the 1960s (World Bank, 1984:83). As a result of these changes in the global economy, the terms of trade for Africa have deteriorated by 10 to 30 percent over the last few years (World Bank, 1983b).

On one hand, this has reduced their ability to import. On the other, it has increased debt problems and created a setback in capital accumulation. Debt problems are most severe in Sudan, Zaire, Uganda, and Madagascar, which have been forced to restructure their debts. This results in higher total interest payments, further retarding their capital-flow and long term development plans. As a consequence a significant proportion of foreign-exchange receipts have to be devoted to debt payments rather than imports. The slow rate of capital accumulation is accompanied by a substantial drop in the productivity of investment (i.e. the amount of value added per investment unit) between 1967 and 1979 (World Bank, 1982a:66).

Overall there has been a downward trend in the economic growth in sub-Saharan Africa throughout the 1980s; since 1980 per capita GDP in these countries has fallen by 16 percent (World Bank, 1985:39). As argued by the dependency theorists, this region's dependence on global markets has had adverse effects on indigenous economic growth. Because a large proportion of their GDP is obtained from exports the drop in the price of commodities in the global economy has slowed capital accumulation, economic development, and per capita consumption (World Bank, 1984:82). Moreover, the economic recovery that is taking place in some industrial countries is doing little to improve export prices, earnings, capacity utilization, and growth in Africa (World Bank, 1984:78, 85; 1985:93). The primary problem with export-oriented development is the investment of large amounts of capital into segments of the economy that depend on global markets and prices, which makes the domestic economy vulnerable to minor shifts in global demand. The failure of the policies to encourage economic growth in other segments are so severe that the World Bank, a long-time advocate of export-oriented development, now recommends a movement toward diverse rural economic development (1981b; 1982b:71). Policies that tie capital accumulation to the sale of a few commodities on the global economy have restricted limited long-term growth. ${ }^{10}$ To avoid the social and economic problems created by market fluctuations, development strategies must be directed toward the role technology plays in the economy of the nation as a whole: the capital accumulation process (Cardoso, 1972:91; Amin, 1976; Furtado, 1964:109).

\section{AGRICULTURE VERSUS THE INDUSTRIAL SECTOR}

Development of the urban-industrial sector and specialized agricultural products has undermined economic growth in the rural sector. The agricultural sector is growing less food per capita than it did two decades ago, and the average African who depends on agriculture for a living is poorer today than in 1970 (New York Times, 1986). However, this problem can be overcome by emphasizing comprehensive agricultural and rural development. Several researchers have pointed out that agricultural development must precede industrialization, and only with a productive agricultural sector will other sectors of the economy be stimulated (Acharya, 1978; Anderson and Leiserson, 1980; World Bank, 1982b; Collier and Rempel, 1977; Hinderink and Sterkenburg, 1983; Johnston, 1978; Leidholm and Chuta, 1976; Rogge, 1977; Rutman, 1972; and Swaminathan, 1983). Low productivity in the agricultural sector impedes the revolutionizing of agricultural production by offering few incentives. Moreover, because of low productivity in this sector, food must be imported. This situation depletes vital foreign exchange (Wolff, 1981:4).

A critical reason why modernizationists' policies have not succeeded is that complex technologies used in urban-industrial development are not understood by the domestic population. The typical worker (usually a migrant from the rural area) placed in the urban-industrial sector has little knowledge of the productive process. As a result, agencies that introduce technology into this environment must depend on foreign labor to operate and repair the machinery. Under these conditions the diffusion of technology into other sectors of the economy is unlikely to occur as modernizationists suggest.

In addition to promoting urban migration, the emphasis on urbanindustrial development undermines agricultural development. In countries such as Lesotho, Botswana, and Swaziland migration to South African industries has reduced the young male population as a source of agricultural labor and has resulted in the impoverishment of their agriculture (Elkan, 1980:593-96). ${ }^{11}$ Agricultural output has either stagnated or increased at a rate that is less than the growth rate of the population (World Bank, 1983a:66, 71). Once agriculturally self-sufficient Lesotho is now dependent on imported food to meet domestic needs. Although women perform a major role in 
agricultural production in these societies, it is impossible for them to fulfill the labor shortages created by the mass migration of the male population.

\section{TECHNOLOGY AND AGRICULTURAL POLICY: A PROPOSAL}

With a population growth rate of approximately 2.5 percent (Anthony et al., 1979:16), and the increased demand for food on a global scale (Swaminathan, 1983: 562-64) African agricultural development is essential. First, increased production is necessary to feed its growing population. Second, a diverse agricultural production and processing sector can become a significant source of capital accumulation. Unlike traditional exports from LDCs (i.e. minerals, crude oil, specialty agricultural and industrial goods), the demand for basic agricultural goods is more stable because it is tied to the size of the population.

However, the production of basic agricultural goods in sub-Saharan Africa has been hampered by a lack of incentive and available labor. Unlike most underdeveloped regions, Africa's shortage of rural workers is a major obstacle to agricultural development (Anthony et al., 1979:28; Berry, 1975; Blair, 1977; Essany and Mubawonku, 1975; and Mubogunje, 1976). For example, in Western Nigeria, which ranks as one of the most densely populated regions in Africa, approximately 18 million acres or about seventy percent of its land mass remains uncultivated at any one time (Rogge, 1977:254).

Although the factors which have contributed to low productivity in African agriculture are complex two issues are clear. First, low productivity has not encouraged workers to pursue technological innovation (Blair, 1977). Second, the lack of agricultural workers presents a structural condition that prevents the maximization of production and the development of arable lands. Development of this sector, where the people have expertise in the production process, is necessary to keep up with the growing demand for food (see Hinderink and Sterenburg, 1983:22; and Kamarck, 1971:126). Obviously the rural worker must learn to adapt new machinery and techniques to agricultural production. However, this alternative is more viable than urban-industrial development. One advantage of pursuing agricultural development is that the farmer already has knowledge of climatic change, soil fertility, and basic production techniques. Moreover, Opare (1977) found that knowledge of the principles of production is the most important predictor of agricultural success.

Mechanization of agriculture can maximize land usage and alleviate labor shortages while increasing productivity. Although early efforts to mechanized agriculture were not always successful, these failures lie primarily in its misapplication rather than in something internal to the technology itself. For example, short planting seasons encourage governments to provide tractorhire services to help farmers plow the land and plant larger crops. In Uganda in the late 1960s, approximately 60 percent of the hours worked by the tractor-hire service were spent plowing (Brown et al., in Anthony et al., 1979: 142). The large crops only aggravated labor shortages during the harvest season when operations were carried out manually. In Kenya, on the other hand, tractors used in the rice irrigation system allowed farmers to plant within the necessary timetable. This resulted in increased productivity and an openness by local farmers to accept now improved techniques. With the introduction of tractor drawn equipment thorough land preparation becomes possible, which ensures the successful completion of planting and field operations.

Irrigation systems can also increase agricultural production. Within subSaharan Africa, as a whole, there is a large proportion of successful rainfed agriculture. However, there are also large areas where rainfall is varied and the total amount received is low. Within these areas evaporation rates are high and crop failure from drought has been a long-term hazard (Anthony, et al., 1979:27, Wolff, 1981). The introduction of irrigation systems into Kenya has significantly enhanced rice production in the Mwea/Tebere region (Anthony et al., 1979:147). Moreover, increased productivity encourages cooperation between local farmers and agricultural extension programs, which provides the basis for future innovation (Opare, 1977). In the Sudan this has resulted in successful pest control practices (Anthory et. al., 1979:265). Guy-Hunter has outlined three simple but necessary conditions to secure agricultural innovation: the new practice must be feasible for the farmer; it must pay better than present practices; and the product must be marketable (1973:236).

The application of technology must be closely monitored and tested to assure its success. This means that technology must be applied to those sectors of the agricultural system that generate profits and encourage investments. Studies of farmers in LDCs indicate that they will "quickly drop their attachment to traditional methods when they are presented with the economic incentives to do so" (Grabowski, 1979:729; also see Anthony et al.,1979; Schultz, 1964; Shingi et al., 1981). For example, by pursuing an aggressive agricultural policy Zimbabwe has increased its per capita income from $\$ 470$ in 1979 to $\$ 740$ in 1983 (Wold Bank, 1981a:31; 1985:85). The 
country also currently produces surplus grain (New York Times, 5-27-86). It has done this despite being affected by the recent drought.

\section{TECHNOLOGY IN THE PROCESSING SECTOR}

In addition to the mechanization of agricultural production, technological innovation in processing agricultural goods has immense potential to provide cheaper food and stimulate capital accumulation. For example, the labor intensive nature of the Tanzanian cashew processing industry is a major factor restricting Tanzania from competitively processing the crop locally. Whereas Tanzania produces more than 25 percent of the world's cashew nuts, it processes only 10 percent of its crop (Chudson, 1976:91). The remaining 90 percent is shipped to India for processing and then to markets in North America, Europe, and the Soviet Union. This undermines capital accumulation because approximately 50 percent of the raw nut price is accrued between the time the product is exported and its final market destination. The foreign exchange loss to Tanzania is approximately $\$ 13.2$ million annually. ${ }^{12}$

Processing provides immense employment and capital accumulation opportunities. In Nigeria estimates suggest that approximately 30,000 persons could be employed in export processing alone. If processing for the domestic market were included the number would be substantially increased (Anthony et al., 1979:62). Cotton ginning, palm oil extraction, and nut processing appear to be the major agricultural activities that offer the most potential to enhance capital accumulation. In the lumber industry, sawmilling, and plywood production provide similar opportunities. The introduction of technology becomes extremely important in the processing of perishable crops such as palm oil and tea. To avoid spoilage these products should be processed locally. Moreover, factories can be located in close proxximity to the production sites, which encourages rural nonfarm employment and avoids the sectoral inequalities that result from urban-industrial development. Moreover, development of the agricultural sector can stimulate smiall-scale industrial growth. In Sierra Leone a 10 percent increase in agriculture generated a 16 percent increase in the demand for small-scale industrial products (Liedholm and Chuta, 1976:90). ${ }^{13}$

In brief, a successful agricultural sector requires processing agricultural products as well as planting, cultivating, and harvesting. This has not been the strategy in Africa. As a consequence the stages of production where the majority of the capital is accumulated occur outside sub-Saharan Africa.
The initial step to development must link the various phases of the production process.

\section{SUMMARY AND DISCUSSION}

Sub-Saharan Africa's unique characteristics make the adoption of laborsaving techniques essential if this region is to increase its productive capacities. The key to its success is redirecting investment into rural development where it will benefit the majority of the population: Obviously financial restrictions make this a gradual process. However, investment capital is not the most serious problem. The major obstacle is overcoming the exiting class alliances between local elites and foreign capitalist classes.

Aside from the social reasons (e.g. hunger, migration, poverty) there are two important economic reasons for this policy change. First, investment in technology for producing and processing agricultural products is less expensive than urban-industrial development, and it benefits a larger segment of the population. Second, a sound agricultural system will provide a stable economic base which, unlike urban-industrial development, stimulates growth in other sectors and can lead to comprehensive development. Mechanization can enhance capital accumulation and allow subSaharan Africa to recapture valuable foreign exchange. The introduction of labor-saving techniques frees labor to engage in surplus production for trade. Once this process begins self-reliance and comprehensive independent development are possible. This type of technology transfer can lead to the autonomous creation of technology that suits the needs of a particular society. This can increase productivity and capital accumulation, and reduce the economic gap between he çountries of Africa and their developed counterparts in North America and Europe. If the introduction of technology is not directed toward rural development, policy makers are willfully or unwittingly making decisions that are against the interest of most Africans.

\section{ENDNOTES}

1. Technology in this context indicates knowledge of techniques of production organization as well as technological innovation of production machines and equipment.

2. No attempt is made to discuss cases outside of sub-Saharan Africa such as India and China. The discussion is limited to the sub-Saharan region 
because of its unique conditions.

3. The importance of the compatibility between the economic and cultural system is discussed in more detail by Raffaele (1971).

4. For example, between 1960 and 1975 the GDP per capita increased by $\$ 5045$ in the developed countries. In contrast, in African countries the increase was only $\$ 451$. If Gabon and Libya, where exceptionally rapid growth rates occurred, were excluded the average increase in GDP per capita for the continent drops to $\$ 196$. Moreover, several West African countries have experienced decreases in per capita income in the 1980s (World Bank, 1983a:70; New York Times, May 27, 1986).

5. Several authors have pointed out that in Africa, unlike other regions of the global economy (e.g. Latin America), these alliances are with political rather than economic elites. An economic elite of significant size or strength does not exist because the most dynamic sectors of the economy have been controlled by foreign capital since colonization. The small economic elite that does exist is employed by transnational corporations as operators and managers of their enterprises rather than as collaborators with foreign capitalists (Magubane, 1976:191-93). However, the lack of a significant domestic capitalist class has not substantively altered Africa's connections to the global economy. It has generated a type of dependent-development characterized by employer-employee relationships rather than joint-ventures between peripheral and core capital as in other regions of the global. economy. The result is the alliances of political elites with foreign capital. Transnational corporations supply the capital required to promote development of the modern sector, while the state protects these investments by enacting protective tariffs and import restrictions (Bates, 1981: 62-77). Moreover, indigenous political elites often hold directorates in both private firms and companies that have been formed as joint ventures between foreign capital and the domestic government (Bates, 1981:103-5).

6. Manufacturing plays a substantial role in Hong Kong, India, Singapore, and Korea. The agricultural and oil producing/mining categories re main the basic sectors in Africa, the Middle East, and most of Central and South America.
7. For Amin, capital accumulation is important primarily to facilitate the transition to socialism. Although this issues is not a concern here, his analysis of capital accumulation does apply.

8. Amin is aware that a gap between the traditional and the modern sectors will occur, however he argues that inequality is a necessary condition of development and this inequality will cause social unrest and change. The temporary sacrifice of equality in favor of increased productivity presents serious questions. However, as the traditionalagricultural sector becomes more productive, inequality will be minimized because it is typically a result of uneven internal development. On the other hand, some authors argue that the introduction of more productive techniques does not necessarily entail less equality (Bornschier and Hoby, 1981:376). Although their research does not specify types of development this is an encouraging challenge to conventional wisdom (also see Shingi et al., 1981).

9. It is important to note that current growth rates in the developed countries have major implications for sub-Saharan Africa where much of the GDP is realized through the sale of export commodities. The tendency for the prices of primary products in the LDCs to fall in relation to prices of industrial products exported in the developed countries is not a new finding (see Singer, 1950). However, the slow growth in the global economy makes this connection particularly important.

10. Capital accumulation is also restricted in the manufacturing sectors in LDCs that are tied to the global economy. For example, the textile and electronic assembly industries, which require little technology and large amounts of labor are rapidly being delegated to the LDCs where cheap labor exists (Landsberg, 1979). This leads to continued labor exploitation, the commodity many developmentalists view as the LDCs most valuable resource (Brown, 1977:264, 267). Wages are depressed because of low productivity associated with labor intensive production. This results in slow capital accumulation, which reinforces the existing wage structure necessary to protect profits. Since capital accumulation is tied to the intensity of capital in the productive process, development of this sector offers little opportunity for economic growth. Moreover, the lack of organized labor in LDCs creates a vicious circle of exploitation. 
11. Urban-industrial development contributes to the deterioration of soil fertility and agricultural productivity because without proper care the soil becomes less productive. Hence, when the migrant workers return from an extended absence previous productivity levels are not achieved.

12. This phenomenon is not confined to Tanzania. Mozambique, the world's largest producter of nuts, also exports its cashew crop to India for processing.

13. A related problem with development in Africa has been the lack of linkages between manufacturing/industry and agriculture. If linkages and a feedback system between the farmers and the manufacturers are developed, farm equipment can be produced and repaired within the region. This can also stimulate the shift to the mechanization of agriculture.

\section{REFERENCES}

Acharga, Shanke

1978 "Perspectives and Problems of Development in Low Income, Sub-Sahara Africa." World Bank Working Paper, 300.

Agarwal, Anil

1980 "Science and Technology: An Agonizing Reappraisal." Third World Quarterly, 2:2 (April). Amin, Samir

1974 Accumulation on a World Scale: A Critical Theory of Development. New York: Monthly Review Press.

1976 Unequal Development: An Essay of the Social Formations of Peripheral Capitalism. New York: Monthly Review Press.

Anderson, Dennis and Mark Leiserson

"1980" "Rural Nonfarm" Employment in Developing Countries." Economic Development and Cultural. Change, 28:2

Anthony, Kenneth, Bruce Johnston, William Jones, and Victor Uchendu

1979 Agricultural Change in sub-Saharan Africa. Ithaca: Cornell University Press.

Baron, C.

1980 "Technological Choice and Transfer in Food Processing in Developing Countries: An Overview," in Christopher B. Baron (ed.) Technology Employment and Basic Needs in Food Processing in Developing Countries. Oxford: Pergamon.

Barratt-Brown, Michael

1974 The Economics of Imperialism.Nottingham: The Russell Press Limited.

Bates, Robert

1981 Markets and States in Tropical Africa: The Political Basis of Agricultural Policies. Berkeley: Berry, S.S. University of California Press.

1975 Cocoa, Custom, and Socio-Economic Change in Rural Western Nigeria. Oxford: Clarendon Press.
Blair, James

1977 "Migration of Agricultural Manpower in Sierra Leone." Journal of Economic and Social Geography, 4.

Bodenheim, Susanne

1971 "Dependency and Imperialism The Roots of Latin American Underdevelopment." Politics and Society, 1:3.

Bornshier, Volker and Jean-Pierre Hoby

1981 "Economic Policy and Multinational Corporations in Development: The Measurable ImBradshaw, York pacts In Cross-National Perspective." Social Problems, 28:4.

1977 "Appropriate Technology and the Grass Roots: Toward a Development Strategy from the Bottom Up." The Developing Economies, 15:3.

Brown, R.H.

1977 “Appropriate Technology and the Grass Roots: Toward a Development Strategy from the Bottom Up." The Developing Economies, 15:3.

Cardoso, Fernando Henrique

1972 "Dependency and Development in Latin America." New Left Review, 74.

1982 Development Under Fire." In Harry Makler, Alberto Martinelli and Neil Smelser: The New Intemational Economy. Beverly Hills: Sage Publications Inc.

Chudson, Walter

1976 "Foreign Investment and the Acquisition of Technology: Kenya and Tanzania," in D. Babatunde Thomas (ed.), Importing Technology into Africa. New York: Praeger Publishers. Collier, Valerie and Henry Rempel

1977 "The Divergence of Private from Social Cost in Rural-Urban Migration: A Case Study of Nairobi, Kenya." The Joumal of Development Studies, 13:3.

\section{Critchfield, Richard}

1982 "Science and the Villager: The Last Sleeper Wakes." Foreign Affairs, 61:1 (Fall). Eisenstadt, S.N.

1966 Modemization: Protest Change.Englewood Cliffs: Prentice-Hall, Inc.

Elkan, Walter

1980 "Labor Migration from Botswana, Lesotho, and Swaziland." Economic Development and Cultural Change, 28:3

Emmanuel, Arghiri

1972 Unequal Exchange: A Study of the Imperialism of Trade. New York: Monthly Review.

1974 . "Myths of Development Versus Myths of Underdevelopment." New Left Review 85 Essang, S.M., and A.F. Mabawanku

1975 "Impact of Urban Migration of Rural Development: Theoretical Considerations and

Evans, Peter

1979 Dependent Development: The Alliance of Multination, State, and Local Capital in Brazil. Princeton: Princeton University Press.

1977 "Multinationals, State-owned Corporations, and the Transformation of Imperialism: a Brazilian Case Study." Economic Development and Cultural Change, 26.

Fanon, Frantz

1967 The Wretched of the Earth. Harmondsworth: Penguin Books.

Frank, Andre Gunder

1967 Capitalism and Underdevelopment in Latin America. New York: Monthly Review Press. Furtado, Celso

1964 Developmental Underdevelopment. Berkeley: University of California Press.

Galtung, Johan

1980 The True Worlds: A Transnational Perspective. New York: The Free Press. 
Grabowski, Richard

1979 "The Implications of an Induced Innovation Model." Economic Development and Cultural Change, 27:4.

Hannay, Bruce and Robert McGinn

1980 "The Anatomy of Modern Technology: Prolegomenon to an Improved Public Policy for the Social Management of Technology." Daedalus, 109:1 (Winter).

Hinderink, J. and J.J. Sterkenburg

1983 "Agricultural Policy and Production in Africa: Aims, Methods and Means." The Joumal of Modern African Studies, 21:1.

Hunter, Guy

1973 "Agricultural Administration and Institutions." Food Research Institute Studies, 12.

Inkeles, Alex and David Smith

1974 Becoming Modem: Individual Change in Six Developing Countries. Cambridge: Harvard University Press.

Jequier, N. $\quad$ Technot Technology. Oxford: Pergamon Press.

Johnston, Bruce

1978 "Agricultural Production Potentials and Small Farmer Strategies in Sub-Saharan Africa." World Bank Staff Working Paper, 300.

Kamrack, Andrew

1971 The Economics of African Development. London: Praeger Publishers. Landsberg, Martin Landsberg, Martin

1979 "Export-Led Industrialization in the Third World: Manufacturing Imperialism." The Review of Radical Political Economics, 11:4.

Liedholm, Carl and Enyinna Chuta

1976 "The Economics of Rural and Urban Small-Scale Industries in Sierra Leone." African Rural Economy Paper, 14. Michigan State University.

Mabogunje, Akin

1976 "Settlement Policies and the Transformation of Traditional Economies." Habitat Inter national, 3:3/4

Magdoff, Harry

1978 Imperialism: From the Colonial Age to the Present. New York: Monthly Review.

Magubane, Bernard

1976 "The Evolution of the Class Structure in Africa," in Reter Gutkind and Immanuel Wallerstein (eds.) The Political Economy of Contemporary Africa.Beverly Hills: Sage.

Malik, Yogendra

1982 "Attitudinal and Political Implications of Diffusion Technology: The Case of North Indian Youth." Joumal of Asian and African Studies, 17:1-2.

McRobie, George

1979 "Intermediate Technology: Small is Successful." Third World Quarterly, 1:2 (April). New York Times, May 27, 1986

Nwosu, E.J.

1975 "Some Problems of 'Appropriate' Technology and Technology Transfer." The Develop ing Economies, 13:1.

1977 "The Role of Agricultural Extension in the Adoption of Innovations by Cocoa Growers in Ghana." Rural Sociology, 42:1.

Porter, Julia, and Alfred Lathan-Koenig

1969 "Intermediate Technologies." Development Digest, 7:1
Prechel, Harland

1985 "The Effects of Exports, Public Debt, and Development on Income Inequality." The Sociological Quarterly, 26:2 (Summer).

Prechel, Harland and Alan Sica

1986 "Demonstrating Dependency: Ideologies, Quantitative Tests, and the Enigma of Education." Political Power and Social Theory, 6. Greenwich: JAI Press.

Raffaele, Joseph

1971 The Economic Development of Nations. New York: Random House.

Rogge, John

1977 . "Rural Development Problems in Africa: Some Lessons from Western Nigeria." The Canadian Geographer, 21:3

Robinson, Austin

979 "The Availability of Appropriate Technologies," in Austin Robinson (ed.) Appropriate Technologies for Third World Development. New York: St. Martin's Press.

Rostow, Walt

1971 The Stages of Economic Growth: A NonCommunist Manifesto, (2nd ed.). Cambridge: Cambridge University Press.

Rutman, Gilbert

1972 "Regional Development in Southern Africa with Special Reference to the Transkei," in Sayre Schatz (ed.), South of the Sahara: Development in African Economies. Philadelphia: The Temple University Press.

Schultz, T.W.

1964 Transforming Traditional Agricultural. New Haven: Yale University Press.

Schumacher, E.F.

1973 Small is Beautiful: Economics as if People Mattered. New York: Harper \& Row, Publishers. Shingi, Prakash, Frederick Fliegel, and Joseph Kivlin

1981 "Agricultural Technology and the Issue of Unequal Distribution of Rewards: An Indian Case Study." Rural Sociology, 46:3

Singer, Hans

1950 "The Distribution of Gains Between Investing and Borrowing Countries." American Economic Review, XL (May).

Stewart, F. and P. Streeter

1976 "New Strategies for Development: Poverty, Income Distribution and Growth." Oxford Economic Papers, 28.

Swaminathan, M.S.

1983 "Ägricultural Progress-Key to Third World Prosperity." Third World Quarterly, 5:3 (July). Thirlwall, A.P.

1972 Growth and Development. Cambridge: Schenkman Publishing Company

Thompson, Scott

1978 The Third World: Premise of U.S. Policy. San Francisco: Institute for Contemporary Studies. Vajpayi, Dhirendra

1982 "Modernity and Industrial Culture of Indian Elites." Journal of Asian and African Studies, $17: 1 / 2$.

Wolf, Anthony

1981 "Good News No News, It Has Yet to Become a Household Word." World Bank RF Illus trated, 5:2 (May).

World Bank

1981a "GNP Growth Falls in 1980." Report: News and Views from the World Bank, Sept.-Oct.

$1981 \mathrm{~b}$ Accelerated Development in Sub-Saharan Africa. Washington: D.C.

1982a The World Bank Annual Report, 1982. Washington, D.C. 
1982b "Study Suggests Solutions for a Continent in Crisis." Report: Newus and Views from the World Bank. Washington, D.C.

1983a The World Bank Annual Report, 1983. Washington, D.C.

1983b "Sub Bank, (August-September). Washington, D.C.

1984 The World Bank Annual Report. Washington, D.C.

1985 The World Bank Annual Report. Washington, D.C
FEDERAL COURT PROCESSING OF CORPORATE, WHITE COLLAR, AND COMMON CRIME ECONOMIC OFFENDERS OVER THE PAST THREE DECADES

Kirk A. Johnson

Washburn University

Mid-American Review of Sociology, 1986 Vol. XI, No. 1:

The history of white-collar and corporate crime in our nation has been one of toleration. Throughout much of this century, the victims, the government, and the criminal justice system have been largely inactive in attempting to control this form of law-violating behavior. As a result, occupational and organizational crime offenders have been treated preferentially in our courts when compared to traditional or common crime offenders. Beginning in the 1970s, however, public attitudes began to change and the government and criminal justice system were given a mandate to pursue these offenders. This paper utilizes aggregate data on the U.S. District Courts for the fiscal years ending June 30,1964, 1974, and 1984, and is designed to investigate whether a shift in criminal justice policy (arising from public concerns over corporate and white-collar crime) has been put into effect. That is, have equitable operational policies for the adjudication and sentencing of corporate, white-collar, and common crime offenders evolved over the past three decades? The conclusions drawn from the data suggest that while corporate and white-collar criminals are more frequently being brought to the attention of the courts, and have been receiving more and more serious sanctions, they are still receiving more lenient penalties for their actions than are common property crime offenders.

\section{INTRODUCTION}

Since its inception, the American criminal justice system has been primarily oriented toward the apprehension, prosecution, adjudication, and punishment of working-class offenders who, by necessity and social placement, disproportionately engage in the more visible predatory acts of traditionally-defined property theft and conversion (see Balkan, et al. 1980; 